\title{
PEMANFAATAN KITOSAN DARI CANGKANG RAJUNGAN (Portonus sanginolentus L.) SEBAGAI PENGAWET IKAN KEMBUNG (Rastrelliger sp) DAN IKAN LELE (Clarias Batrachus)
}

\author{
Rika Silvia, Sari Wahyu Waryani, Farida Hanum \\ Departemen Teknik Kimia, Fakultas Teknik, Universitas Sumatera Utara, \\ Jl. Almamater Kampus USU Medan 20155, Indonesia \\ Email : rikal9a_sb@yahoo.co.id
}

\begin{abstract}
Abstrak
Penggunaan senyawa anti mikroba yang tepat dapat memperpanjang umur simpan suatu produk serta menjamin keamanan produk. Untuk itu dibutuhkan bahan sebagai anti mikroba yang alami supaya tidak membahayakan bagi kesehatan. Penggunaan kitosan untuk menghambat aktivitas mikroba pada ikan kembung (Rastrelliger sp) dan ikan lele (Clarias batrachus) akan diuji efektivitasnya. Pada penelitian ini kitosan yang digunakan sebagai anti mikrobia diekstraksi dari cangkang rajungan (Portunus sanginolentus L.). Kitin dan kitosan yang berhasil diekstraksi dikarakteristik hasilnya meliputi pengujian kadar air, kadar abu, dan derajad deasetilasi. Kitosan setelah dikarakteristik, digunakan sebagai anti mikroba ikan kembung (Rastrelliger sp) dan ikan lele (Clarias batrachus). Kitosan dilarutkan dalam asam asetat $1 \%$ dengan variasi konsentrasi kitosan $1 \%, 1,5 \%, 2 \%$, dan 2,5\%. Lama waktu penyimpanan ikan: 0 jam, 10 jam, 15 jam, 20 jam, dan 25 jam. Hasil penelitian kitosan berbentuk butiran/ bubuk, kadar air 5\%, kadar abu 2\% serta derajat deasetilasi yakni sebesar 61,08\%. Hasil uji larutan kitosan terhadap ikan menunjukkan bahwa pengawetan ikan dengan cara perendaman yaitu penambahan kitosan 1,5\% merupakan variabel terbaik dan dapat memperpanjang umur simpan ikan selama lebih dari 5 jam sedangkan pengawetan ikan dengan cara penyemprotan variabel terbaik yaitu penambahan kitosan 2,5\% dan dapat memperpanjang umur simpan ikan kurang dari 5 jam.
\end{abstract}

Kata kunci: kitosan, rajungan, ekstraksi, derajat deasetilasi

\begin{abstract}
The use of appropriate anti-microbial compounds can extend the shelf life of a product as well as ensure the safety of the product. That requires a material that is naturally anti-microbial so as not harmful to health. The use of chitosan to inhibit microbial activity on mackerel (Rastrelliger sp) and catfish (Clarias batrachus) to test it's effectiveness. In this research chitosan that used as an antimicrobial extracted from the shells of crabs (Portunus sanginolentus L.). Chitin and chitosan that were successfully extracted were characterized it's results includes moisture content testing, ash content, and degrees of deacetylation. Characterized chitosan, were used as an anti-microbial mackerel (Rastrelliger sp) and catfish (Clarias batrachus). Chitosan was dissolved in 1\% acetic acid with varying concentrations of chitosan as 1\%, $1.5 \%, 2 \%$, and $2.5 \%$. The storage time of fish: 0 hours, 10 hours, 15 hours, 20 hours, and 25 hours. The results of research chitosan form as granules / powder, 5\% moisture content, ash content $2 \%$ and the degree of deacetylation which amounted to $61,08 \%$. Chitosan solution test results on fish showed that fish preservation by soaking with chitosan addition of $1.5 \%$ was the best variable and could extend the shelf life of fish more than 5 hours while fish preservation by spraying gave the best variable with addition of chitosan $2.5 \%$ and could extend the shelf life of fish less than 5 hours.
\end{abstract}

Key words: chitosan, crabs, ekstraction, degrees of deacetylation

\section{Pendahuluan}

Indonesia merupakan negara perairan dengan hasil laut yang terus meningkat ditiap tahunnya. Potensi lestari sumber daya ikan di perairan laut Indonesia diperkirakan mencapai 6,4 juta per tahun [3], di samping itu masih banyak masalah yang harus ditanggapi serius dalam pelestarian sumber daya ikan ini, salah satunya yakni pembusukan ikan.

Pembusukan ikan terjadi segera setelah ikan ditangkap atau mati. Pada kondisi suhu tropik, ikan membusuk dalam waktu 12-20 jam tergantung spesies, alat atau cara penangkapan. Pendinginan akan memperpanjang masa simpan ikan. Pada suhu $15-20^{\circ} \mathrm{C}$, ikan dapat disimpan hingga sekitar 2 hari, pada suhu $5^{\circ} \mathrm{C}$ tahan selama 5-6 hari, sedangkan pada suhu $0^{\circ} \mathrm{C}$ dapat mencapai 9-14 hari, tergantung spesies ikan [9].

Maraknya penggunaan bahan tambahan pangan sebagai pengawet yang tidak diijinkan untuk digunakan dalam makanan seperti formalin dan borak yang membahayakan bagi kesehatan [9], telah mendorong banyak pihak untuk mencari alternatif bahan pengawet yang lebih sehat. Salah satu bahan alami yang dapat diharapkan sebagai 
pengawet alternatif yang potensial adalah kitosan [7].

Pemilihan rajungan sebagai bahan baku pembuatan kitosan di dasarkan pada kadar kitin yang tinggi yakni berkisar antara 20-30\% dan bahan yang mudah di dapat karena banyak di konsumsi masyarakat, sedangkan pemilihan aplikasi sebagai pengawetan ikan di karenakan oleh produksi serta nilai ekspor ikan yang tinggi di Indonesia[15].

Teori

Kitin adalah senyawa karbohidrat yang termasuk dalam polisakarida tersusun atas monomer-monomer asetil glukosamin yang saling berikatan. Kitin merupakan bahan organik utama terdapat pada kelompok hewan seperti, crustaceae, insekta, fungi, mollusca dan arthropoda. Struktur kitin tersusun atas 2000- 3000 satuan monomer Nasetil D-Glukosamin yang saling berikatan melalui 1,4-glikosidik [12].

Kitosan yang disebut juga dengan $\beta-1,4-2$ amino-2-dioksi-D-glukosa merupakan turunan dari kitin melalui proses deasetilasi. Kitosan juga merupakan suatu polimer multifungsi karena mengandung tiga jenis gugus fungsi yaitu asamamino, gugus hidroksil primer dan skunder. Adanya gugus fungsi ini menyebabkan kitosan mempunyai reaktifitas kimia yang tinggi. Kitosan merupakan senyawa yang tidak larut dalam air, larutan basa kuat, sedikit larut dalam $\mathrm{HCl}$ dan $\mathrm{HNO}_{3}$, dan $\mathrm{H}_{3} \mathrm{PO}_{4}$, dan tidak larut dalam $\mathrm{H}_{2} \mathrm{SO}_{4}$.

Mikroorganisme dapat menyebabkan bahaya karena kemampuan menginfeksi dan menimbulkan penyakit serta merusak bahan pangan. Mikroorganisme dapat disingkirkan dengan cara dihambat atau dibunuh secara fisik maupun kimia. Bahan antimikroba merupakan salah satu penghambat mikroorganisme secara kimia yang mengganggu pertumbuhan dan metabolisme mikroba. Berdasarkan kelompok mikroorganisme, antimikroba terdiri dari antibakteri, antifungi, antivirus,dan antiprotozoa. Antibakteri adalah zat yang menghambat pertumbuhan bakteri dan digunakan secara khusus untuk mengobati infeksi. Bahan pengawet adalah senyawa yang mampu menghambat dan menghentikan proses fermentasi, pengasaman atau bentuk kerusakan lainnya, atau bahan yang dapat memberikan perlindungan bahan pangan dari pembusukan [7].

\section{Metodologi Penelitian}

\section{Bahan dan Alat}

Bahan yang digunakan adalah kitosan yang di ekstraksi dari cangkang rajungan (Achatina fulica) sebagai pengawet dan Ikan Kembung Kuring (Rastrelliger sp) serta ikan lele (Clarias batrachus) sebagai bahan yang akan diawetkan, asam asetat sebagai bahan pembantu digunakan untuk melarutkan kitosan dengan konsentrasi $1 \% ; 1,5 \%$;
$2 \%$ dan $2,5 \%$ dengan variasi waktu pengawetan 10 , 15,20 , dan 25 jam. Alat utama yang digunakan adalah FT-IR untuk analisa derajat deasetilasi.

\section{Proses Ekstraksi Kitin}

Pembuatan kitin dan kitosan menggunakan metode Hong K. No (1989) sebagaimana telah diterapkan oleh Mahatmanti dkk (2011) dan dikombinasikan dengan metode No et al. (1989), yang telah dimodifikasi (Purwatiningsih 1993; No \& Meyers 1997), sebagaimana telah diterapkan oleh Tanasale et al. (2006). Kulit kepiting rajungan yang telah dikupas tangan dicuci dan dikeringkan di dalam oven pada suhu $80{ }^{\circ} \mathrm{C}$ selama 24 jam lalu dihaluskan kemudian disaring dengan ayakan berukuran 50 mesh [19]. Sebanyak 120 gram serbuk cangkang rajungan ditempatkan dalam wadah kemudian ditambahkan $\mathrm{NaOH}$ 3,5\% sebanyak $1200 \mathrm{~mL}$ dengan perbandingan $(1: 10)$, kemudian dipanaskan pada suhu $65{ }^{\circ} \mathrm{C}$ selama 2 jam sambil diaduk. Setelah campuran dingin, disaring dengan menggunakan kertas saring dan dicuci dengan akuades sampai netral. Setelah kondisi netral tercapai, residu yang diperoleh kemudian dikeringkan pada suhu $60{ }^{\circ} \mathrm{C}$ selama 4 jam hingga kering. Kemudian residu hasil deproteinasi ditambahkan larutan $\mathrm{HCl} \quad 1,0 \quad \mathrm{~N}$ dengan nisbah 1:15 (w/v) dan dibiarkan selama 30 menit pada suhu kamar sambil diaduk. Kemudian campuran disaring dengan menggunakan kertas saring dan dicuci dengan akuades sampai netral. Setelah kondisi netral tercapai, residu yang diperoleh kemudian dikeringkan pada suhu $60{ }^{\circ} \mathrm{C}$ selama 4 jam hingga kering.

\section{Transformasi Kitin enjadi Kitosan}

Sebanyak 50 gram kitin ditambahkan dengan $500 \mathrm{~mL} \mathrm{NaOH} \mathrm{50 \%} \mathrm{denganperbandingan} \mathrm{(1:10)}$ dalam wadah dan diaduk sambil dipanaskan pada suhu $100{ }^{\circ} \mathrm{C}$ selama 30 menit. Setelah campuran dingin, disaring dengan menggunakan kertas saring dan dicuci dengan akuades sampai netral. Setelah kondisi netral tercapai, residu yang diperoleh kemudian dikeringkan pada suhu $60{ }^{\circ} \mathrm{C}$ selama 4 jam hingga kering. Produk deasetilasi ini dinamakan kitosan.

\section{Pengawetan Ikan}

Pengawetan ikan menggunakan metode Ahmad M dkk (2003) yang diterapkan oleh Mahatmanti dkk (2011) dimana Untuk mencari optimalisasi kitosan sebagai bahan pengawetan kitosan maka kitosan yang digunakan divariasi konsentrasinya dengan cara melarutkan kitosan (w/v) kedalam asam asetat $1 \%(\mathrm{v} / \mathrm{v})$ (Susanti dkk, 2013). Sampel ikan kembung (Rastrelliger sp) dan ikan lele (Clarias batrachus). yang diambil dari tambak, kemudian ditimbang untuk diketahui 
massanya. Sampel ikan masing-masing direndam dalam larutan kitosan dengan konsentrasi yang bervariasi dengan perbandingan $1 \mathrm{~kg}$ ikan/1 L larutan kitosan. Penyimpanan dilakukan dengan variasi waktu serta cara pemberian larutan pengawetan ikan.

\section{Karakterisasi Kitosan}

Kitosan hasil ekstraksi dari cangkang rajungan sebelum digunakan sebagai pengawet dilakukan pengujian kadar air, kadar abu, dan derajat deasetilasi. Derajat deasetilasi ditentukan dengan metode baseline dilterapkan oleh Mahyudin dan Sumaryanto [10]. Derajat deasetilasi dapat diukur dengan metode spektrofotometri inframerah dengan teknik film pada sel kalium bromida. Kitosan dilarutkan dalam asam asetat $1 \%$, teteskan pada sel kalium bromida dan diratakan kemudian dibiarkan kering sehingga membentuk lapisan film. Buat spektrum kitosan dengan FTIR kemudian derajat deasetilasi dapat dihitung dengan metode baseline. Nilai serapan dapat dihitung dengan persamaan 1 :

$\mathrm{A}=\log \mathrm{Po} / \mathrm{P}$

Di mana :

$\mathrm{P}=$ jarak antara garis dasar dan puncak

$\mathrm{Po}=$ jarak antara garis dasar dengan garis singgung

Derajat deasetilasi dapat dihitung dengan persamaan (2).

$\%$ Deasetilasi $=\left\{1-\left(\frac{A_{1655}}{A_{1440}} \times \frac{1}{1,3 a}\right)\right\} \times 100 \%$

Dimana:

$\mathrm{A}_{1655}=$ nilai serapan pada $1655 \mathrm{~cm}^{-1}$

$\mathrm{A}_{3450}=$ nilai serapan pada $3450 \mathrm{~cm}^{-1}$

1,33 = perbandingan $\mathrm{A}_{1655}$ dengan $\mathrm{A}_{3450}$ pada derajat deasetilasi $100 \%$

\section{Karakterisasi Ikan}

Ikan sebelum dan setelah pengawetan dilakukan pengujian nilai $\mathrm{pH}$, Organoleptik (fisik), dan TVB (Total Volatile Base). Nilai TVB dihitung dengan menggunakan Metode Cawan Conway sesuai SNI No.01-2369-1991 dalam Kusumaningrum dan Doddy [8]. Pengujian TVB dilakukan untuk ikan sebelum dan sesudah pengawetan. Sampel halus sebanyak \pm 5 gram ditambahkan $20 \mathrm{~mL} 5 \%$ TCA kemudian dihaluskan lagi (homogenkan). Larutan sampel disaring dengan kertas saring, diambil filtratnya. Bila filtrat yang diperoleh belum jernih maka dilakukan sentrifus pada $3.000 \mathrm{rpm}$ selama 10 menit. $1 \mathrm{~mL}$ sampel jernih dimasukkan ke bagian luar kiri cawan Conway dan ditambahkan $1 \mathrm{~mL}$ $1 \%$ asam borat di bagian dalam cawan. Bagian kanan luar cawan ditambahkan $2 \mathrm{~mL} \mathrm{~K}_{2} \mathrm{CO}_{3}$ jenuh dalam $2 \mathrm{M} \mathrm{NaOH}$. Cawan ditutup dan diolesi vaselin agar tidak bocor. Setelah diinkubasi selama
2 jam pada suhu $37-40{ }^{\circ} \mathrm{C}$, larutan borat bagian tengah cawan di tetesi indikator BCG-MR kemudian dititrasi dengan $0,01 \mathrm{~N} \mathrm{HCl}$ sampai berwarna merah.

Kadar TVB dapat dihitung dengan persamaan (3):

(ml titrasi sampel-ml titrasi blanko)xN HclX14,007 Berat sampel(gr)

\section{Hasil dan Pembahasan \\ Karakterisasi Kitosan}

Dunia perdagangan sudah memiliki standar kualitas kitosan yang diproduksi secara massal dan sudah umum diaplikasikan (komersil). Adapun karakteristik kitosan yang digunakan dalam penelitian ini dapat dilihat pada Tabel 1 berikut ini: Tabel 1 Karakterisasi Kitosan [16]

\begin{tabular}{|c|c|c|}
\hline \multirow[b]{2}{*}{ Parameter } & \multicolumn{2}{|c|}{ Karakteristik Kitosan } \\
\hline & $\begin{array}{c}\text { Bahan } \\
\text { Penelitian }\end{array}$ & Standar Kitosan \\
\hline $\begin{array}{l}\text { Ukuran } \\
\text { Partikel }\end{array}$ & Butiran/ bubuk & Butiran/ bubuk \\
\hline Kadar Air & $5 \%$ & $<10 \%$ \\
\hline Kadar Abu & $2 \%$ & Maksimal 2\% \\
\hline $\begin{array}{l}\text { Derajat } \\
\text { deasetilasi }\end{array}$ & $61,08 \%$ & Minimal $70 \%$ \\
\hline
\end{tabular}

\section{Karakterisasi Ikan Hasil Pengawetan}

Pada penelitian ini, ikan sebelum dan sesudah pengawetan dilakukan berbagai analisa yang berguna sebagai karakterisasi ikan seperti anaslisa TVB (Total Volatile Base), analisa pH dan analisa organoleptik. Untuk menunjang hasil analisa, peralatan yang digunakan untuk analisa sebelumnya telah di sterilisasi.

\section{Analisa TVB (Total Volatile Base)}

Analisa Total Volatile Base adalah salah satu metode pengukuran untuk menentukan kesegaran ikan yang didasarkan pada akumulasi senyawasenyawa basa seperti amoniak, trimetialamin, dan senyawa volatile lainnya yang menguap [12]. Perubahan nilai TVB ikan lele (Clarias Batrachus) pada penelitian ini dapat dilihat pada Gambar 1.

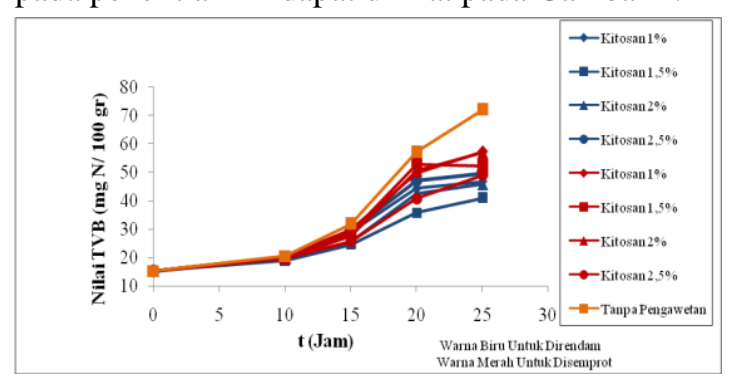

Gambar 1. Pengaruh Waktu Pengawetan terhadap Nilai TVB Ikan Lele (Clarias Batrachus) pada Berbagai Variasi Konsentrasi Kitosan 
Dari gambar 1 dapat dilihat bahwa nilai TVB ikan sebanding dengan lama waktu pengawetan dimana sesuai dengan penelitian sebelumnya yang menyebutkan bahwa nilai TVB meningkat seiring dengan bertambahnyawaktu penyimpanan ikan pada semua perlakuan [18].

Dari gambar 1 dapat dilihat ikan lele (Clarias Batrachus) tanpa pengawetan tidak layak konsumsi pada jam ke-15 dengan nilai TVB ikan $31.82 \mathrm{mg}$ N/ 100 gr. Untuk ikan lele (Clarias Batrachus) yang diawetkan dengan cara perendaman kitosan hasil maksimum didapat pada konsentrasi kitosan $1,5 \%$ selama 15 jam dengan nilai TVB ikan 24,56 mg N/ 100 gr, dan dengan kitosan 2,5\% selama 15 jam merupakan hasil minimum dengan nilai TVB ikan 29,87 mg N/ 100 gr. Sedangkan pengawetan ikan lele (Clarias Batrachus) cara penyemprotan dengan kitosan 2,5\% selama 15 jam merupakan hasil maksimum dengan nilai TVB ikan 25,67 mg N/ 100 gr, dan kitosan $1 \%$ selama 15 jam merupakan hasil minimum dengan nilai TVB ikan 29,91 mg N/ 100 gr, nilai TVB ini masih tergolong ikan layak konsumsi, karena menurut [5] dikatakan tidak layak dikonsumsi jika ikan memiliki nilai TVB lebih dari $30 \mathrm{mg} \mathrm{N} / 100 \mathrm{~g}$.

Untuk mengetahui pengaruh waktu terhadap nilai TVB ikan kembung (Rastrelliger sp)dalam berbagai konsentrasi kitosan, seperti yang di gambarkan pada gambar 2 .

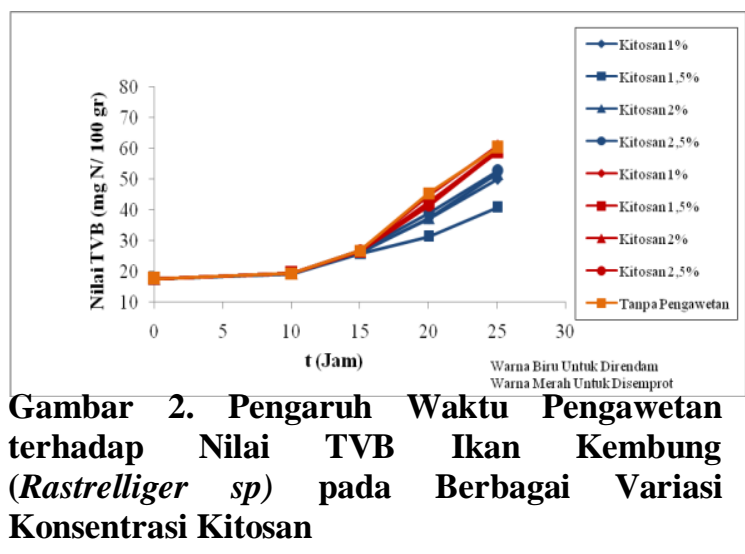

Dari gambar 2 menunjukkan ikan kembung (Rastrelliger $s p$ ) tanpa pengawetan masih layak konsumsi pada jam ke-15 dengan nilai TVB ikan $26,71 \mathrm{mg}$ N/ 100 gr. Untuk pengawetan ikan kembung (Rastrelliger $s p$ ) dengan perendaman kitosan 1,5\% selama 15 jam merupakan hasil maksimum yaitu dengan nilai TVB $25,77 \mathrm{mg} \mathrm{N} /$ 100 gr, dan dengan kitosan 2,5\% selama 15 jam merupakan hasil minimum dengan nilai TVB ikan 26,65 mg N/ 100 gr. Sedangkan pengawetan ikan kembung (Rastrelliger sp) dengan penyemprotan kitosan 2,5\% selama 15 jam adalah variabel terbaik dengan nilai TVB 26,52 mg N/ 100 gr dan kitosan 1\% selama 15 jam merupakan hasil minimum dengan nilai TVB ikan $26,69 \mathrm{mg}$ N/ 100 gr

Dari analisa yang telah dilakukan dalam penelitian ini, disimpulkan bahwa telah sesui dengan teori, menurut penelitian sebelumnya larutan kitosan dalam asam asetat mempunyai potensi untuk memperpanjang daya awet ikan [1] dengan konsentrasi kitosan yang mempunyai nilai rata-rata tertinggi aspek kenampakan, dan bau adalah larutan kitosan dengan konsentrasi 1,5\% [13]. Pola kemunduran mutu ikan yang disimpan pada suhu kamar, hanya dapat disimpan hingga 12 jam pada suhu kamar [2].

\section{Analisa pH (power of hydrogen)}

Nilai $\mathrm{pH}$ (power of hydrogen) merupakan salah satu indikator yang digunakan untuk menentukan tingkat kesegaran ikan. Pada proses pembusukan ikan, perubahan $\mathrm{pH}$ daging ikan sangat besar peranannya karena berpengaruh terhadap proses autolisis dan serangan bakteri.

Untuk mengetahui perlakuan yang baik dengan berbagai variasi waktu dan konsentrasi kitosan pada pengawetan ikan lele ( Clarias Batrachus) maka dilakukan analisa $\mathrm{pH}$ ikan yang dapat dilihat pada Gambar 3.

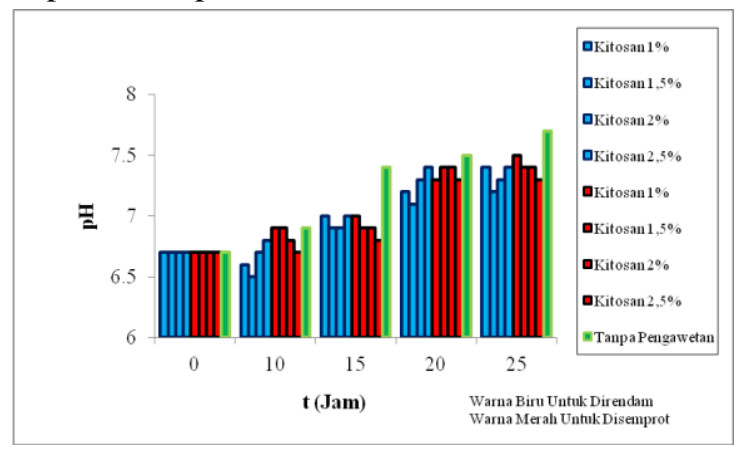

Gambar 3. Pengaruh Waktu Pengawetan terhadap pH Ikan Lele (Clarias Batrachus) pada Berbagai Variasi Konsentrasi Kitosan

Dari gambar 3 dapat dilihat bahwa sebagian besar grafik menunjukkan penurunan $\mathrm{pH}$ dalam jangka waktu tertentu yang kemudian mengalami kenaikan $\mathrm{pH}$. Kondisi pH pada ikan mengalami penurunan disebabkan glikolisa/glikogen dalam tubuh berubah menjadi asam laktat yang akan menambah derajat keasaman dalam daging ikan tersebut. Asam laktat ini terkait gerak ikan sesaat akan mati dimana ikan cenderung untuk banyak bergerak dan menggelepar. Semakin banyak asam laktat yang terdapat dalam tubuh ikan selain menyebabkan $\mathrm{pH}$ menurun juga akan memperpendek masa rigor mortis ikan. Apabila mutu ikan semakin menurun maka kerja bakteri pembusuk semakin meningkat [6]. Jika cadangan 
glikogen telah habis terurai maka $\mathrm{pH}$ daging akan berhenti mengalami penurunan. Penguraian protein dan komponen selain protein yang mengandung nitrogen selama proses kemunduran mutu akan meningkatkan $\mathrm{pH}$ daging ikan, dan semakin tinggi tingkat pembusukan maka akan semakin tinggi pula $\mathrm{pH}[11]$.

Pada gambar 3 menunjukkan pengawetan ikan lele (Clarias Batrachus) dengan perendaman kitosan $1,5 \%$ merupakan hasil maksimum, dan 2,5\% merupakan hasil minimum. Sedangkan pengawetan ikan lele (Clarias Batrachus) dengan penyemprotan kitosan $2,5 \%$ adalah hasil maksimum sedangkan hasil minimum di dapat pada konsentrasi kitosan $1 \%$. Dimana perubahan pH pada konsentrasi tersebut tidak terlalu signifikan dari $\mathrm{pH}$ ikan sebelum pengawetan Menurut Amlacher, 1961; Eskin,1990 dalam [14] Nilai pH ikan segar berada pada kisaran di bawah netral hingga netral, yang menandakan bahwa ikan berada pada kondisi rigormortis.

Sebagai bahan pembanding antara pengawetan ikan air tawar dalam penelitian ini juga dilakukan pengawetan ikan air asin (laut) seperti ikan kembung (Rastrelliger sp). Hubungan waktu pengawetan ikan kembung (Rastrelliger sp) terhadap $\mathrm{pH}$ pada suhu kamar disajikan pada gambar 4

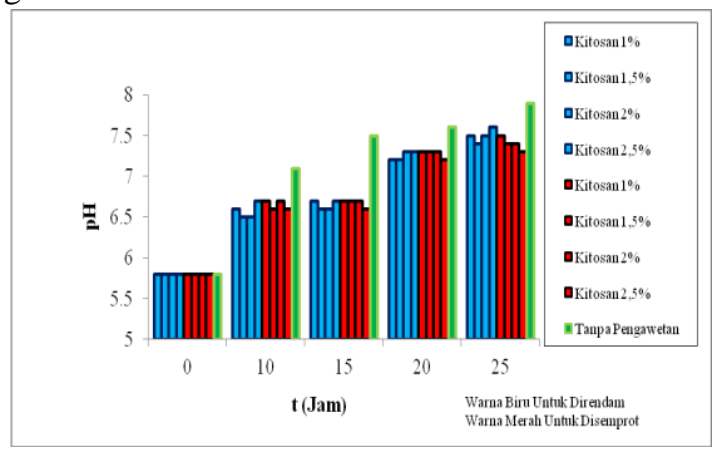

Gambar 4. Pengaruh Waktu Pengawetan terhadap pH Ikan Kembung (Rastrelliger sp) pada Berbagai Variasi Konsentrasi Kitosan

Dari gambar 4 menunjukkan pengawetan ikan kembung (Rastrelliger sp) dengan perendaman kitosan 1,5\% merupakan hasil maksimum dan hasil minimum didapat pada pengawetan ikan kembung (Rastrelliger sp) dengan perendaman kitosan 2,5\% . Sedangkan pengawetan ikan kembung (Rastrelliger $s p$ ) dengan penyemprotan kitosan 2,5\% adalah hasil maksimum dan penyemprotan kitosan $1 \%$ adalah hasil minium. Peningkatan $\mathrm{pH}$ merupakan indikasi terjadinya penurunan kualitas karena semakin tinggi $\mathrm{pH}$ maka kesempatan mikrob untuk merusak akan semakin besar. Jika berkaitan dengan $\mathrm{pH}$ maka bakteri merupakan mikroorganisme yang paling cepat berkembang dibandingkan kapang dan ragi [7].

Jika membandingkan hasil diatas, pengawetan dengan ikan lele (Clarias Batrachus) lebih baik dari pada pengawetan dengan Ikan Kembung (Rastrelliger sp. Hal ini mungkin disebabkan lamanya waktu pelelangan yang menyebabkan bberkurangnya kesegaran ikan, sesuai dengan pendapat Eskin (1990) bahwa setelah ikan mati, sirkulasi darah terhenti yang mengakibatkan runtutan perubahan yang terjadi dalam otot/jaringan ikan [11].

\section{Analisa Organoleptik}

Analisa organoleptik meliputi kenampakan mata, insang, lendir permukaan badan, daging (warna dan kenampakan), bau, dan tekstur. Hasil uji organoleptik ikan lele pada penelitian ini dapat dilihat pada gambar 5

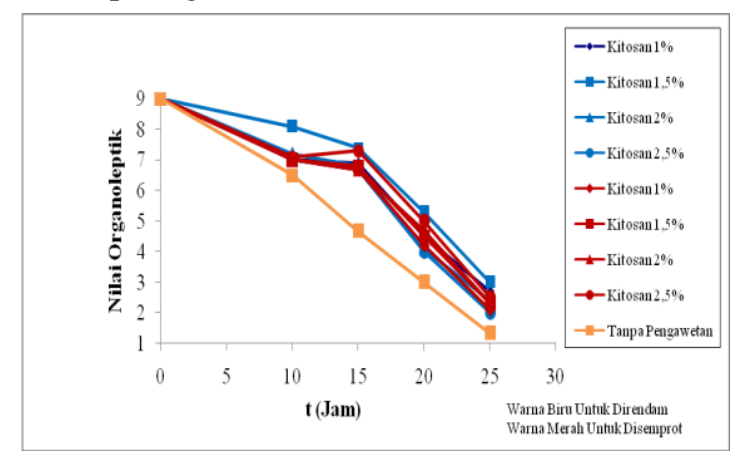

Gambar 5. Pengaruh Waktu Pengawetan terhadap Nilai Organoleptik Ikan Lele (Clarias Batrachus) pada Berbagai Variasi Konsentrasi Kitosan

Pada Gambar 5 terlihat bahwa nilai organoleptik ikan lele (Clarias Batrachus) yang tidak diawetkan pada jam ke 15 yaitu 4,67. Pengawetan ikan lele (Clarias Batrachus) yang diawetkan dengan perendaman hasil maksimum didapat pada konsentrasi kitosan 1,5\% dengan nilai organoleptik 7,4 lama pengawetan 15 jam dan hasil minimum didapat pada konsentrasi kitosan 2,5\% dengan nilai organoleptik 6,7 dengan lama pengawetan 15 jam, sedangkan dapat terlihat pula bahwa nilai organoleptik ikan lele (Clarias Batrachus) yang diawetkan dengan penyemprotan hasil maksimum didapat pada konsentrasi kitosan $2,5 \%$ dengan nilai organoleptik 7,3 lama pengawetan 15 jam dan hasil minimum didapat pada konsentrasi kitosan $1 \%$ dengan nilai organoleptik 6,7 dengan lama pengawetan 15 jam. Hal ini membuktikan bahwa pengawetan dengan berbagai variasi seperti yang di jelaskan sebelumya telah memenuhi syarat standar mutu ikan segar secara organoleptik berdasarkan sesuai sesuai SNI 01-2729-1992 (standar nilai mutu = min. 7). 
Dilakukan pula uji organoleptik untuk mengetahui pengaruh pengawetan ikan Kembung (Rastrelliger sp)dengan menggunakan kitosan dalam berbagai variasi seperti pada gambar 6 di bawah ini.

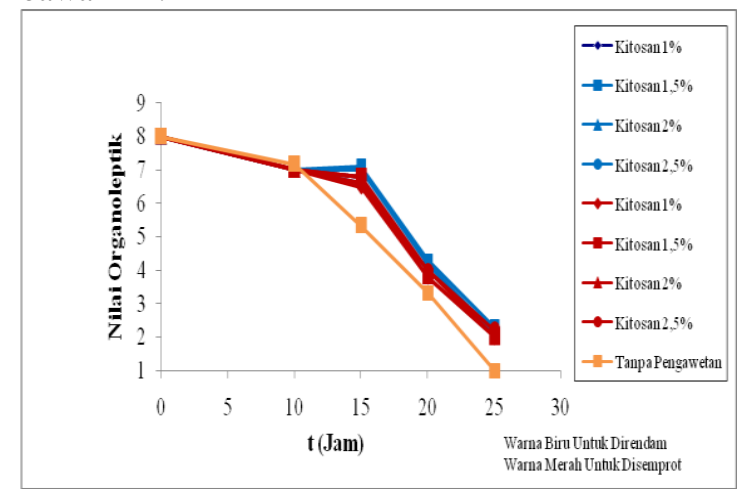

Gambar 6. Pengaruh Waktu Pengawetan terhadap Nilai Organoleptik Ikan Kembung (Rastrelliger sp) pada Berbagai Variasi Konsentrasi Kitosan

Dari gambar 6 dapat dilihat bahwa nilai organoleptik ikan sebanding dengan lama penyimpanan untuk nilai organoleptik ikan Kembung (Rastrelliger sp) yang tidak diawetkan pada jam ke 15 yaitu 5,33. Pengawetan ikan Kembung (Rastrelliger $s p$ ) yang diawetkan dengan perendaman hasil maksimum didapat pada konsentrasi kitosan 1,5\% dengan nilai organoleptik 7,1 lama pengawetan 15 jam dan hasil minimum didapat pada konsentrasi kitosan 2,5\% dengan nilai organoleptik 6,6 dengan lama pengawetan 15 jam, sedangkan dapat terlihat pula bahwa nilai organoleptik ikan Kembung (Rastrelliger $s p$ ) yang diawetkan dengan penyemprotan hasil maksimum didapat pada konsentrasi kitosan 2,5\% dengan nilai organoleptik 7 lama pengawetan 15 jam dan hasil minimum didapat pada konsentrasi kitosan $1 \%$ dengan nilai organoleptik 6,5 dengan lama pengawetan 15 jam pula Hal ini mungkin disebabkan kesalahan saat menganalisa atau kesegaran ikan kembung yang sudah menurun sebab ikan saat proses produksi dan pelelangan mengalami penurunan dikarenakan adanya proses perubahan glikogen menjadi asam laktat [20]

\section{Kesimpulan}

Perlakuan terbaik dari pengwetan ikan dengan cara perendaman yaitu penambahan kitosan 1,5\% . Sedangkan perlakuan terbaik dari pengwetan ikan dengan cara penyemprotan yaitu penambahan kitosan 2,5\%. Pengawetan dengan menggunakan kitosan dapat memperpanjang umur simpan ikan selama \pm 5 jam

\section{DAFTAR PUSTAKA}

[1] Ariani dan Y. Yennnie. "Pengawetan Pindang Ikan Layang (Decapterus russelli)". Jurnal Pascapanen dan Bioteknologi Kelautan dan Perikanan Vol. 3 No. 2, 2008

[2] Ariyani, J. T. Murtini, N. Indriati, Dwiyitno, dan Y. Yenni. "Penggunaan Gliserol Untuk Menghambat Penurunan Mutu Ikan Mas Segar". Jurnal Perikanan( J. Fish. Scl.) IX (1):125-133 ISSN:0853-6384. Pusat Riset Pengolahan Produk dan Sosial Ekonomi Kelautan dan Perikanan, Badan Riset Kelautan dan Perikanan, 2012.

[3] Ariyanti, "Karakteristik Daging Rajungan (Portonus pelagicus) Industri Rumah Tangga, Desa Gegunung Wetan Kabupaten Rembang Jawa Barat" Skripsi Program Studi Teknologi Hasil Perikanan Fakultas Perikanan dan Ilmu Kelautan Institut Pertanian Bogor, 2007.

[4] Badan Standarisasi Nasional [BSN].

“ Petunjuk Uji Organoleptik Ikan Segar Standar Nasional Indonesia. SNI-01-23462006. Jakarta:Standar Nasional Indonesia.2006.

[5] Erlangga. "Kemunduran Mutu Fillet Ikan Lele Dumbo (Clarias Gariepinus) Pada Penyimpanan Suhu Chilling dengan Perlakuan Cara Kematian”. Skripsi. Program Studi Teknologi Hasil Perikanan Fakultas Perikanan Dan Ilmu Kelautan Institut Pertanian Bogor, 2009.

[6] Kasmiati, Metusalach dan Rahmatang. "Analisis Hubungan Antara Berbagai Faktor dengan Kualitas Ikan Yang Ditangkap Menggunakan Purse Seine" Studi Kasus Ps. Pemanfaatan Sumberdaya Perikanan, Jurusan Perikanan, Fakultas Ilmu Kelautan dan Perikanan, Universitas Hasanuddin, 2013.

[7] Kusumaningjati."Potensi Antibakteri Kitosan Sebagai Pengawet Alami pada Tahu”. Skripsi Program Studi Biokimia Fakultas Matematika dan Ilmu Pengetahuan Alam Institut Pertanian Bogor, 2009.

[8] Kusumaningrum dan Doody. "Kajian Mutu Kimiawi Bakso Asap Dari Udang Putih (Penaeus Merguiensis) Pada Berbagai Variasi Konsentrasi Dan Waktu Perendaman Dalam Asap Cair" Jurnal Teknologi Pertanian 4(1): 25-30, Agustus 2008 ISSN 1858-2419. Universitas Mulawarman, 2008.

[9] Mahatmanti, W. Sugiyo, dan W. Sunarto. "Sintesis Kitosan dan Pemanfaatannya Sebagai Anti Mikrobia Ikan Segar". Laporan PenelitianFakultas Matematika dan Ilmu Pengethuan Alam. Universitas Negeri Semarang, 2011. 
[10] Mahyudin dan Sumaryanto.” Aplikasi Reaktor Sistem Sinambung dan Teknologi Membran pada Produksi enzim Amilase oleh Bacillius subtilis". Fakultas Farmasi Universitas Pancasila, Srengseng Sawah, Jagakarsa, Jakarta Selatan, 2014.

[11] Metusalach, Kasmiati, Fahrul, dan I. Jaya. " Analisis Hubungan antara Cara Penangkapan dan Cara penanganan dengan kualitas ikan yang dihasilkan". Laporan Hasil Penelitian LP2M. Unhas, 2012.

[12] Rahmadani, D. Susanti, T. A. Soripada, dan R. Silaban. "Pemanfaatan Kitosan Dari Limbah Cangkang Bekicot Sebagai Adsorban Logam Tembaga". Laporan Penelitian Jurusan Kimia FMIPA. Universitas Negeri Medan, 2013.

[13] Rokhima, Ima. "Efektivitas Perendaman Ikan Segar dalam Larutan Kitosan dari Limbah Cangkang Udang Terhadap Sifat Fisik Ikan Segar”. Unnes Journal of Public Health. Jurusan Ilmu Kesehatan Masyarakat.

[14] Sasonto, Fie Ling dan Ratna Handayani. "Pengaruh Pengkomposisian dan Penyimpanan Dingin Terhadap Perubahan Karakteristik Surimi Ikan Pari (Trygon sp.) dan Ikan Kembung (Rastrelliger sp.)”. Hasil Penelitian Departemen Teknologi Hasil Perairan, Fakultas Perikanan dan Ilmu Kelautan IPB. 2012.

[15] Sedjati. "Pengaruh Konsentrasi Khitosan Terhadap Mutu Ikan Teri (Stolephorus Heterolobus) Asin Kering Selama Penyimpanan Suhu Kamar" Tesis Program Studi Magister Manajemen Sumberdaya Pantai. Universitas Diponegoro. 2006.

[16] Siswina, Rida Marta. "Kitosan Sebagai Edible Coating Pada Ikan Lele Dumbo (Clarias Gariepinus) Asap Yang Dikemas Vakum Selama Penyimpanan Suhu Ruang" Skripsi Departemen Teknologi Hasil Perairan Fakultas Pertanian dan Ilmu Kelautan Institut Pertanian Bogor. 2011.
[17] Susanti, Happy Nursyam, dan Anik Martinah. " Effect of Chitosan Modified Process from Shrimp Shell (Littopenaeus vannamei) toward the Fat Oxidation of Tuna Fish Fillet (Thunus thunus)" J. Life Sci. Biomed. 3(3): 264-267, 2013 Fisheries and Marine Faculty, University of Brawijaya, Indonesia. 2013.

[18] Susanto, Tri W. Agustin, Fronthea Swastawawi, Titi Surti, Akhmad S. Fahmi, Mahmud F. Albar, dan Muhammad K. Nafis. "Pemanfaatan Bahan Alami Untuk Memperpanjang Umur Simpan Ikan Kembung (Rastrelliger Neglectus)". Jurnal Perikanan (J. Fish. Sci.) XIII (2): 60-69 ISSN: 0853-6384. Program Studi Teknologi Hasil Perikanan, Jurusan Perikanan, Fakultas Perikanan dan Ilmu Kelautan, Universitas Diponegoro . 2011.

[19] Tanasale, Amos Killay, dan Marsela S. Laratmase. "Kitosan dari Limbah Kulit Kepiting Rajungan (Portunus sanginolentus L.) sebagai Adsorben Zat Warna Biru Metilena". Jurnal Natur Indonesia 14(2), Febuari 2012: 165-171. Jurusan Kimia, Fakultas Matematika dan Ilmu Pengetahuan Alam, Universitas Pattimura, Ambon. 2012.

[20] Wangsadinata V. "Sistem Pengendalian Mutu Ikan Swanggi (Priacanthus macracanthus) (Studi Kasus di CV Bahari Express, Pelabuhan Ratu, Sukabumi)". Skripsi IPB Bogor. 2008.

[21] Wiyatna, Irba U. Warsono, dan Aminuddin Prakkasi. "Pengaruh Tepung Cangkang Rajungan (Portunus Pelagicus) Sebagai Sumber Kitin Dalam Ransum Terhadap Kandungan Lemak Feses Dan Efisiensi Pakan Tikus Putih (Rattus Norvegiccus) Strain Wistar". Laporan Penelitian Fakultas Peternakan Universitas Padjajaran. 2009. 